Article

\title{
Bamboo Biochar Pyrolyzed at Low Temperature Improves Tomato Plant Growth and Fruit Quality
}

\author{
Ratna G. Suthar ${ }^{1}$, Cun Wang ${ }^{2}$, M. Cecilia N. Nunes ${ }^{3}{ }^{\circledR}$, Jianjun Chen ${ }^{4, *}$, Steven A. Sargent ${ }^{5}$, \\ Ray A. Bucklin ${ }^{1}$ and Bin Gao ${ }^{1, *(\mathbb{D})}$ \\ 1 Department of Agricultural and Biological Engineering, University of Florida, Gainesville, FL 32611, USA; \\ rsuthar@ufl.edu (R.G.S.); bucklin@ufl.edu (R.A.B.) \\ 2 Tropical Crops Genetic Resources Institute, 571737 Haikou, Hainan, China; wangcun1984@aliyun.com \\ 3 Department of Cell Biology, Microbiology and Molecular Biology, University of South Florida, \\ Tampa, FL 33620, USA; mariacecilia@usf.edu \\ 4 Department of Environmental Horticulture, Mid Florida Research and Education Center, \\ Apopka, FL 32703, USA \\ 5 Department of Horticultural Sciences, University of Florida, Gainesville, FL 32611, USA; sasa@ufl.edu \\ * Correspondence: jjchen@ufl.edu (J.C.); bg55@ufl.edu (B.G.)
}

Received: 25 August 2018; Accepted: 21 September 2018; Published: 2 October 2018

\begin{abstract}
As a soil amendment, biochar can significantly improve soil quality and crop growth Few studies, however, have explored biochar effects on crop quality. This study investigated the amendment effects of bamboo biochar pyrolyzed at different temperatures on plant growth and fruit quality of tomato (Solanum lycopersicum L.). Tomato 'Micro-Tom' plants were grown in a sand medium amended with 0,1 , and $3 \%$ of biochars produced at $300{ }^{\circ} \mathrm{C}, 450{ }^{\circ} \mathrm{C}$, and $600{ }^{\circ} \mathrm{C}$, respectively. Plant growth was monitored, and fruit harvested at the red stage was analyzed for color, texture, soluble solids content, sugars, ascorbic acid, and acidity. Results showed that biochars produced at $300{ }^{\circ} \mathrm{C}$ and amended at $3 \%$ or pyrolyzed at $450{ }^{\circ} \mathrm{C}$ and amended at $1 \%$ increased plant growth index. Contents of glucose, fructose, soluble solids, ascorbic acid, and sugar-to-acid ratios of fruits produced from the two treatments were significantly higher than the other treatments. The improved plant growth and fruit quality were related to the higher concentrations of $\mathrm{NO}_{3}, \mathrm{P}, \mathrm{Ca}$, and $\mathrm{Mg}$ in the growing media. Our results suggest that optimizing biochar use can be achieved by targeting biochar production conditions and application rate, which resulted in desirable amendment and fruit quality effects.
\end{abstract}

Keywords: biochar amendment; pyrogenic carbon; tomato; postharvest quality

\section{Introduction}

In today's agricultural practices, biochar is receiving renewed interest as a source of value-added bioproducts and bioenergy. Biochar supports sustainability because it is made from forest and agricultural residues; its application improves physical and chemical properties of soil, increasing agricultural productivity [1]. The highly aromatic structure of biochar is more stable than the organic matter from which it was made, increasing long-term soil carbon sequestration and storage due to its slower rate of degradation to $\mathrm{CO}_{2}$, than most other organic matter [2-4].

Generally, increasing biochar production temperature increases surface area [5]. However, not all biochars are created equal. Potential applications of biochar are dependent on their physical properties, such as surface area, functional groups, and elemental composition [6]. Such physical properties are influenced by biochar production factors, such as the type of feedstock, pyrolysis method, and pyrolysis temperature $[7,8]$. An in-depth comparison of feedstock types and pyrolysis 
temperature by Sun et al. [8] showed that even amongst different feedstocks, biochars produced at higher temperature had larger surface areas. Overall, pyrolysis temperature and feedstock types are the most important factors in determining biochar properties and thus their application.

Biochar's benefits to soil have been attributed to increasing soil water-holding capacity, cation exchange capacity (CEC), and nutrient availability [9-13]. The highly porous structure of biochar increases the water-holding capacity of sandy soils, improving the efficiency of water use in agricultural production. Consequently, the largest impact from biochar amendment would likely be seen in sandy soils that have low CECs [14]. Increased crop growth and yield is a commonly reported benefit of amending soils with biochar $[12,15,16]$. The effects of biochar on crop productivity are, however, diverse $[17,18]$. The employment of biochar as a soil amendment in agriculture systems should result in not only increased production but also a positive impact on the nutritional value and overall quality of crops [19].

'Micro-Tom,' a dwarf tomato (Solanum lycopersicum L.) cultivar, is known for its small plant size and rapid growth cycle constituting a convenient model system for research on tomato development and quality $[20,21]$. Color is one of the most important quality attributes affecting tomato appearance and consumer acceptance and has also been shown to be greatly correlated with the lycopene content $[22,23]$. Tomato fruit firmness also has a major impact in consumer acceptability because it is associated with good eating quality and shelf life [24]. In addition to color and firmness, measurements of sugars and acidity can be used to estimate desirable sweet and sour flavor attributes [25]. These sensory and physicochemical quality characteristics of fresh fruits and vegetables are greatly affected by pre-harvest factors, such as weather, moisture content of the soil, use of growth regulators, and soil fertility [26].

Success of biochar application, in most published studies, has limited their definition as either increased yield or above-ground biomass and very little is known about biochar effects on sensorial and psychochemical attributes of fruits and vegetables [27]. One of the few studies showed that a mix of rice husk and cotton seed biochar produced through pyrolysis at $400{ }^{\circ} \mathrm{C}$ enhanced soil water holding capacity under reduced irrigation and also produced fruit with quality comparable to that of tomatoes grown under full irrigation [28].

While previous studies have tested various types of biochars (from different feedstocks) as soil amendment to the growth of crops, few studies have focused on how pyrolysis temperatures affect biochar as soil amendment with respect to the development of plants. Furthermore, there are no studies comparing the effect of soil amendment effects biochar pyrolysis temperature on fruit quality. Thus, the overarching objective of this work was to determine and compare the effects of biochars from different pyrolysis temperatures as soil amendment on tomato growth and quality. Greenhouse growth studies and laboratory analysis of resulting fruit quality were conducted to accomplish the objective.

\section{Materials and Methods}

\subsection{Biochar Production and Characterization}

Bamboo feedstock was collected locally (Gainesville, FL, USA) and dried and pyrolyzed at temperatures of $300{ }^{\circ} \mathrm{C}, 450{ }^{\circ} \mathrm{C}$, and $600{ }^{\circ} \mathrm{C}$ using a furnace apparatus (Bartlett $3 \mathrm{~K}-\mathrm{CF}$, Fort Madison, IA, USA) (Supporting Information). The resulting biochars were used in their pristine form after being ground into fine particles of size smaller than $0.45 \mathrm{~mm}$. The bulk density of the biochars was approximately $0.29 \mathrm{~g} / \mathrm{cm}^{3}$. Major inorganic elements of the biochars were determined by acid digestion of the samples followed by inductively-coupled plasma atomic emission spectroscopic (ICP-AES, Perkin Elmer Optima 2100 DV) analysis. The $\mathrm{N}_{2}$ surface areas of the biochars were determined using the Brunauer-Emmett-Teller (BET) method on Quantachrome Autosorb 1 (Boynton Beach, FL, USA) at $77 \mathrm{~K}$ in the $0.01-0.3$ relative pressure range of the $\mathrm{N}_{2}$ adsorption isotherm. The $\mathrm{CO}_{2}$ surface areas of the biochars were measured with $\mathrm{CO}_{2}$ sorption isotherms at 
273 K. Cation exchange capacity (CEC) and anion exchange capacity (AEC) of the biochars were determined following the procedures published [29].

\subsection{Growth Media}

Coarse white sand (The Sandbag Store, Las Vegas, NV, USA) with particle size from $0.40-0.55 \mathrm{~mm}$ was used as a main medium component. Sand was washed five times with tap water, followed by a wash with deionized water and dried at $80^{\circ} \mathrm{C}$ for one month. Small pots (bottom and top diameters of 7 and $9.5 \mathrm{~cm}$, a height of $7.5 \mathrm{~cm}$, and a volume of $300 \mathrm{~mL}$ ) were filled with coarse sand (up to a volume of $270 \mathrm{~mL}$; the mass of coarse sand at this volume was $435 \mathrm{~g}$ ) that was pre-mixed (on a mass basis) with $0 \%$ (control), $1 \%$, or $3 \%$ of each biochar type $\left(300{ }^{\circ} \mathrm{C}, 450{ }^{\circ} \mathrm{C}\right.$, and $600{ }^{\circ} \mathrm{C}$ ), respectively. Each pot was considered as an experimental unit, and there were either 10 or 15 replicate pots per treatment in different replicated experiments. The resulting treatments will be henceforth referred to as: 300 Low (1\% biochar), 300 High (3\% biochar), 450 Low, 450 High, 600 Low, and 600 High, and control (0\% biochar).

\subsection{Tomato Production}

'Micro-Tom' tomato seeds were purchased from Totally Tomatoes Co. (Randolph, WI, USA) and germinated in 72-cell plug trays with a soilless substrate. Two weeks after germination, seedlings were transplanted singly into pots. All plants were grown in a greenhouse at the University of Florida's Mid-Florida Research and Education Center (MREC) in Apopka, FL. The light intensity of the greenhouse was $2000 \mu \mathrm{mol} / \mathrm{m}^{2} / \mathrm{s}$, the temperature ranged from $20-30{ }^{\circ} \mathrm{C}$, and the relative humidity ranged from $50 \%$ to $100 \%$. A solution was made weekly using Peters Professional 20-20-20 General Purpose fertilizer (Scotts, Maryville, OH, USA) containing a N concentration of $200 \mathrm{mg} / \mathrm{L}$. Plants were fertigated (i.e., both fertilization and irrigation occur at the same time) with the solution being applied once or twice a week depending on plant size. To monitor plant growth, canopy height, widest width, and width perpendicular to the widest width of each plant were recorded. The three measurements were multiplied to give the canopy volume, commonly called plant growth index (GI) as described in Reference [30]. After approximately 9 weeks of transplanting, tomato fruit at the full red color stage were harvested from each plant and weighed. Yield was assessed by counting the total number of full red fruit harvested per plant.

Nutrient status of potting media was examined by analyzing elements in leachates. Three plants from each treatment were randomly selected for leachate collection using the pour through method [31]. Elemental $\mathrm{P}, \mathrm{Ca}$, and $\mathrm{Mg}$ in the leachate were quantified by acid digestion of the samples followed by inductively-coupled plasma atomic emission spectroscopic (ICP-AES) analysis. $\mathrm{NO}_{3}-\mathrm{N}$ in the leachate was determined using the AQ2 Discrete Analyzer (Seal Analytical Inc., Mequon, WI, USA).

\subsection{Fruit Quality Analysis}

Fruit physical properties, such as color and size, were measured right after harvest. Samples intended for compositional measurements were homogenized on the day of harvest and kept frozen at $-30{ }^{\circ} \mathrm{C}$ in air-tight plastic bags until analysis.

Fruit diameter of at least 30 fruits from each treatment was measured for an estimation of size. A total of two color measurements were taken on the opposite sides of the fruit at the equatorial region of each tomato that was large enough to cover the 8-mm aperture of the colorimeter. A hand-held tristimulus reflectance colorimeter (Model CR-400, Minolta Co., Ltd., Osaka, Japan) equipped with a glass light-projection tube (CR-A33f, Minolta Co., Ltd., Osaka, Japan) was used. The color was recorded using the CIE-L*a* $b^{*}$ uniform color space (CIE-Lab), L* (lightness), $a^{*}$ (redness), and $b^{*}$ (yellowness) values. Numerical values of $a^{*}$ and $b^{*}$ were converted into hue angle using the Konica Minolta CR-400 Utility software CR-S4w (2002-2010 Konica Minolta Sensing, Inc., Osaka, Japan).

Fruit firmness was measured using a texture analyzer (model TA.TX Plus, Texture Technologies Corp, NY, USA) fitted with a $35 \mathrm{~mm}$ flat compression plate and equipped with a 50-kg load cell. A tomato fruit was placed stem end down on the flat surface of the texture analyzer, thus applying 
pressure on the blossom-end of the fruit. The plate was then driven with a crosshead speed of $1 \mathrm{~mm}$ $\mathrm{s}^{-1}$, and the compression force was recorded at $3 \mathrm{~mm}$ deformation. The force required to compress the fruit by $3 \mathrm{~mm}$ was recorded in $\mathrm{kgf}$ and then converted to newtons $(\mathrm{N}=\mathrm{kgf} \times 9.8)$.

Total ascorbic acid (AA) was determined using the method described in Reference [32]. Tomato tissue was homogenized and $4 \mathrm{~g}$ of homogenate was mixed with a $20 \mathrm{~mL}$ metaphosphoric acid mixture $\left(6 \% \mathrm{HPO}_{3}\right.$ containing $2 \mathrm{~N}$ acetic acid). Samples were then filtered $(0.22 \mu \mathrm{m})$ prior to high-performance liquid chromatography (HPLC) analysis. AA analysis was conducted using a Hitachi LaChromUltra UHPLC system with a diode array detector and a LaChromUltra C18 $2 \mu \mathrm{m}$ column $(2 \times 50 \mathrm{~mm})$ (Hitachi, Ltd., Tokyo, Japan). The analysis was performed under isocratic mode at a flow rate of $0.5 \mathrm{~mL} / \mathrm{min}$ with a detection wavelength of $254 \mathrm{~nm}$. The sample injection volume was $5 \mu \mathrm{L}$, each with duplicate HPLC injections. The mobile phase was buffered potassium phosphate monobasic $\left(\mathrm{KH}_{2} \mathrm{PO}_{4}\right.$, $0.5 \% w / v)$ at $\mathrm{pH} 2.5$ with metaphosphoric acid $\left(\mathrm{HPO}_{3}, 0.1 \% w / v\right)$. The retention time of the ascorbic acid peak was $2.5 \mathrm{~min}$. The peak was identified after comparison of retention time with the ascorbic acid standard. The total AA content was expressed in terms of the fresh weight (mg AA/100 g).

Individual sugar analysis was conducted using a Hitachi HPLC system with a refractive index detector and a $300 \mathrm{~mm} \times 8 \mathrm{~mm}$ Shodex SP0810 column (Shodex, Colorado Springs, CO, USA) with a SP-G guard column $(2 \mathrm{~mm} \times 4 \mathrm{~mm})$. Aliquots of 4 -g fruit puree were mixed thoroughly with $4 \mathrm{~mL}$ ultrapure water, vortexed, and centrifuged at $1600 \times \mathrm{g}_{\mathrm{n}}$ for $20 \mathrm{~min}$. The supernatant was decanted and filtered through a $0.45 \mu \mathrm{m}$ nylon syringe filter. The sample injection volume was $5 \mu \mathrm{L}$, each with duplicate HPLC injections. The isocratic solvent delivery of water was set at $1.0 \mathrm{~mL} / \mathrm{min}$. The sample injection volume was $5 \mu \mathrm{L}$. Standard solutions of sucrose, glucose, and fructose (Fisher Scientific Company, Pittsburgh, PA, USA) were used to identify sample peaks. The peaks were identified by comparing retention times with those of the standards. The amount of total sugars in tomato was quantified using calibration curves obtained from different concentrations $(2,4,6,10$, and $20 \mathrm{mg} / \mathrm{mL})$ of sucrose, glucose, and fructose standards. Three samples per treatment ( $2 \mathrm{~g}$ fruit puree) were used, each with duplicate HPLC injections. The total sugar and individual sugar contents were expressed in $\mathrm{g} \cdot 100 \mathrm{~g}^{-1}$ fresh weight.

The supernatants of thawed and filtered homogenates were analyzed for titratable acidity (TA), and soluble solids content (SSC). For TA, $6.0 \mathrm{~g}$ aliquots of the supernatant were diluted with $50 \mathrm{~mL}$ distilled water and titrated with $0.1 \mathrm{~N} \mathrm{NaOH}$ to an end point of $\mathrm{pH} 8.2$ with an automatic titrator. Results were converted to percent citric acid using the method described in Reference [33]. The SSC of the supernatant was determined with a digital ATAGO PR-101 refractometer with a $\%$ to $45 \%$ range (Atago, Tokyo, Japan).

\subsection{Statistical Analysis}

Data were subjected to analysis of variance (ANOVA) and Duncan's multiple range tests with the package "agricolae" [34] using R Version 3.1.1 (www.cran.r-project.org). Significant differences between treatments were determined at the $95 \%$ confidence level $(P \leq 0.05)$. All harvests showed significantly different effects for all treatments evaluated and were therefore analyzed separately.

\section{Results \& Discussion}

\subsection{Biochar Properties}

Biochar pyrolyzed at $600{ }^{\circ} \mathrm{C}$ showed the highest surface area while biochar made at $300{ }^{\circ} \mathrm{C}$ had the lowest surface area (Table 1). With increasing pyrolysis temperature, surface area increased, which agrees with previously published findings $[7,8]$. Surface area is one of the most important factors that influence biochars' functionality, as larger surface area results in more porous structures within the biochar $[29,35]$. The $\mathrm{CO}_{2}$ surface area is correlated with presence of micropores $(<1.5 \mathrm{~nm}$ diameter); while the $\mathrm{N}_{2}$ surface area is indicative of mesopores ( $<50 \mathrm{~nm}$ diameter). Both meso- and micropores, inherited from the architecture of the feedstock, can hold air or water, greatly influencing 
the water holding capacity and reducing the bulk density of the entire biochar particle [6]. Because the density of biochar is lower than that of some minerals, biochar application can also change soil bulk density [16]; with possible effects on soil water relations, rooting patterns, and soil microbiota [36].

Elemental analysis of the biochars showed that higher temperature biochars contained higher concentrations of elements (Table 1). Statistical analysis (not shown), however, indicated no significant difference between mineral compositions amongst different temperature-treated chars. The $\mathrm{pH}$ of the biochars ranged from 5.2-7.9, which are within the range of values reported in the literature [8,35]. The biochar produced at $450{ }^{\circ} \mathrm{C}$ had the most acidic $\mathrm{pH}$ at 5.2, whereas the char made at $600{ }^{\circ} \mathrm{C}$ had the most basic at 7.9 (Table 1). Typically, biochars produced at $450{ }^{\circ} \mathrm{C}$ develop more surface functional groups than those of $600{ }^{\circ} \mathrm{C}$ and some of these functional groups, particularly oxygen-containing groups, such as carboxyl, are weakly acidic $[37,38]$. All the three bamboo biochars had relatively high CEC, but low anion exchange ability (Table 1).

For practical application, it is necessary to use biochars with a long-term stability in soil, i.e., they resist various decomposition processes over a long period of time. Singh et al. (2012) explored the stability of different types of biochars and found that the $C$ in plant-based biochars took longer to mineralize than manure-based chars, and also that $\mathrm{C}$ in the lower temperature $\left(400{ }^{\circ} \mathrm{C}\right)$ biochars mineralized faster than that in corresponding higher temperature $\left(550^{\circ} \mathrm{C}\right)$ biochars [39].

Table 1. Basic physicochemical properties of Bamboo Biochar (BB) produced at $300{ }^{\circ} \mathrm{C}, 450{ }^{\circ} \mathrm{C}$, or $600{ }^{\circ} \mathrm{C}$.

\begin{tabular}{|c|c|c|c|c|c|c|c|c|c|c|c|c|c|}
\hline \multirow[t]{2}{*}{ Material } & \multirow{2}{*}{$\begin{array}{c}\begin{array}{c}\mathbf{N}_{2} \\
\text { Surface Area }\end{array} \\
\mathrm{m}^{2} \mathrm{~g}^{-1}\end{array}$} & \multirow{2}{*}{$\begin{array}{c}\mathrm{CO}_{2} \\
\text { Surface Area } \\
\mathrm{m}^{2} \mathrm{~g}^{-1}\end{array}$} & \multirow{2}{*}{$\begin{array}{c}\text { CEC } \\
\mathrm{mmol} \\
100 \mathrm{~g}^{-1}\end{array}$} & \multirow{2}{*}{$\begin{array}{c}\text { AEC } \\
\text { mmol } \\
100 \mathrm{~g}^{-1}\end{array}$} & \multirow[t]{2}{*}{$\mathrm{pH}$} & \multicolumn{8}{|c|}{ Elemental Composition (\% mass based) } \\
\hline & & & & & & $\mathrm{Ca}$ & $\mathrm{Fe}$ & K & $\mathrm{Mg}$ & $\mathrm{Mn}$ & $\mathrm{Na}$ & $\mathrm{P}$ & $\mathrm{Zn}$ \\
\hline $\mathrm{BB} 300^{\circ} \mathrm{C}$ & $\sim 0$ & 178.8 & 30.3 & 1.13 & 6.7 & 0.135 & 0.033 & 0.794 & 0.131 & 0.037 & 0.248 & 0.675 & 0.026 \\
\hline BB $450{ }^{\circ} \mathrm{C}$ & $\sim 0$ & 330.9 & 41.4 & 1.15 & 5.2 & 0.146 & 0.047 & 1.067 & 0.158 & 0.048 & 0.48 & 0.925 & 0.025 \\
\hline $\mathrm{BB} 600^{\circ} \mathrm{C}$ & 247.2 & 493.4 & 73.1 & $\sim 0$ & 7.9 & 0.158 & 0.057 & 1.022 & 0.182 & 0.047 & 0.552 & 0.948 & 0.033 \\
\hline
\end{tabular}

\subsection{Plant Growth}

Growth index (GI) values indicated that all biochar-treated plants had significantly larger GI than the control. A higher significant difference in GI among treatments was seen after 7 weeks into the growth cycle (Figure 1). Particularly, plants from the lower temperature biochar treatments of 450 Low and 300 High had the largest growth index, at nearly twice than that of the control treatment.

Collected leachates were analyzed for concentrations of $\mathrm{NO}_{3}, \mathrm{P}, \mathrm{Ca}$, and $\mathrm{Mg}$ in growing media (Table 2). The mean concentration of these nutrients in the medium amended with $3 \%$ of biochar pyrolyzed at $300^{\circ} \mathrm{C}$ collected during weeks 5,8 , and 10 were the highest among all treatments (Table 2). The higher concentrations coincided with the higher GI as well as best fruit quality parameters (see below). Application of biochar has been shown to increase plant growth by supplying nutrient elements to growing plants, improving water and nutrient holding capacity [28,40], and increased CEC, ultimately preventing leaching of cationic nutrients. Such combined characteristics improve soil fertility, thus accelerate plant growth [41-43]. However, in this study it was not clear why the nutrient elements in some other media were variable and plant GIs were relatively lower. A possible explanation could be that biochar produced at different temperatures had different physical properties, and inappropriate amounts of amendment (too high or too low) could have created root environments that were not suitable for 'Micro Tom' growth. For example, biochars with different combinations of surface areas and CEC may have varied abilities to retain nutrients. Nevertheless, this study showed that even with the same feedstock, biochars produced at different temperatures differ in properties and their use as soil amendment should be carefully tested before large-scale application. 

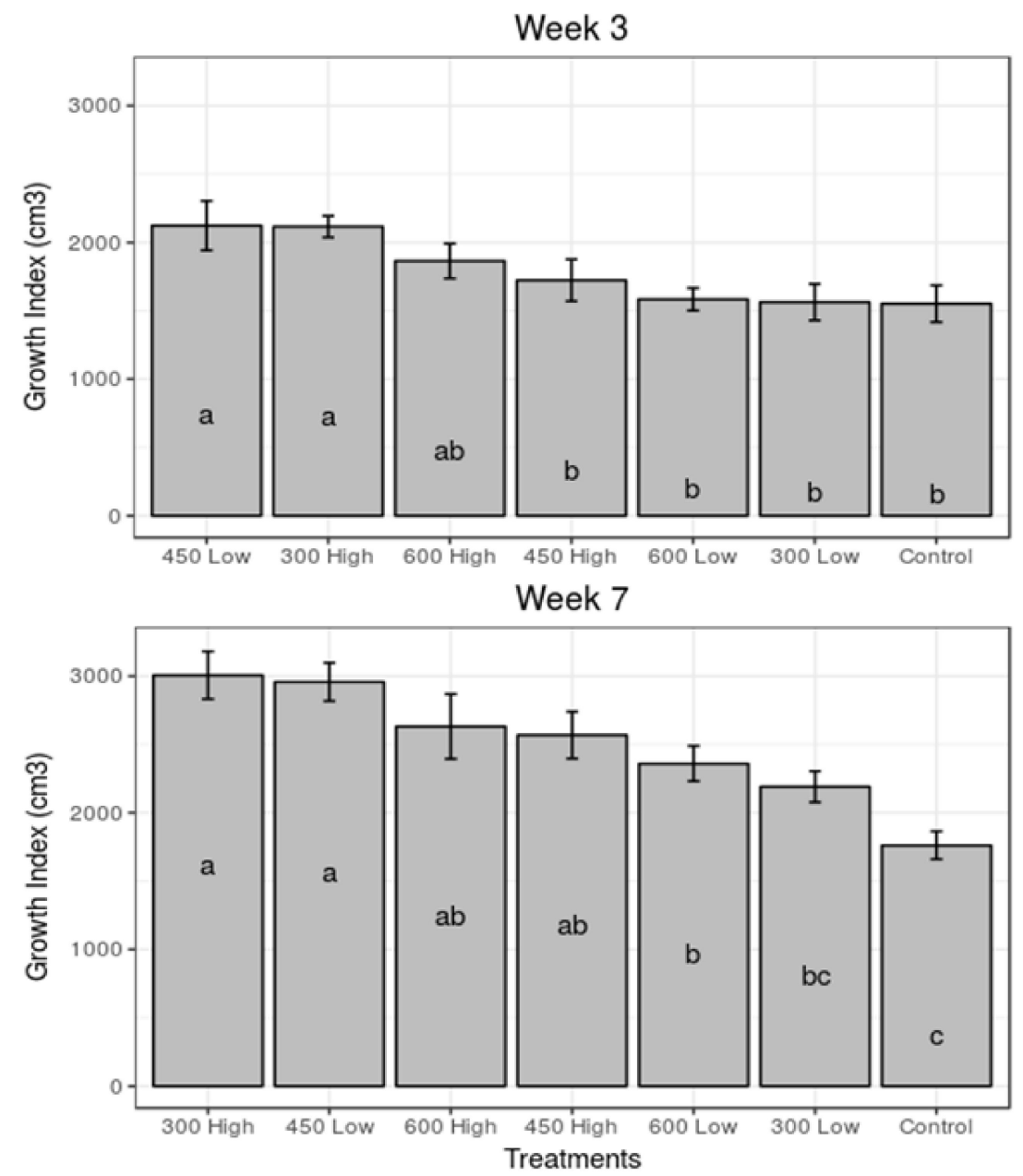

Figure 1. Growth index $\left(\mathrm{cm}^{3}\right)$ of 'Micro-Tom' plants at weeks 3 and 7 of all biochar treatments. Bars represent standard error $(\mathrm{n} \approx 15)$. Different letters show significant difference $(p<0.05)$ between treatments.

Table 2. Mean concentrations (mg/L) of $\mathrm{NO}_{3}, \mathrm{P}, \mathrm{Ca}$, and $\mathrm{Mg}$ in leachates of plant growing media sampled at weeks 5,8 , and 10 *.

\begin{tabular}{lllll}
\hline & $\mathbf{N O}_{3}$ & $\mathbf{P}$ & $\mathbf{C a}$ & $\mathbf{M g}$ \\
\hline Control & 155.2 & 101.97 & 30.25 & 28.21 \\
300 Low & 150.84 & 132.89 & 45.64 & 33.82 \\
300 High & 176.5 & 156.03 & 60.72 & 44.8 \\
450 Low & 165.41 & 101.21 & 38.97 & 26.5 \\
450 High & 149.51 & 77.86 & 50.32 & 37.04 \\
600 Low & 112.9 & 104.65 & 39.52 & 26.2 \\
600 High & 119.3 & 116.68 & 47.1 & 32.08 \\
\hline
\end{tabular}

* Means of leachates collected during week 5,8 , and 10 weeks of plant growth.

Another possibility for the variation in plant growth could be the production of ethylene from the biochar amendment. Ethylene is part of the remaining non-aromatic compounds in fresh biochars, and recent studies showed that ethylene can be generated using fresh biochars [44]. Ethylene effects on plant growth and development, and impacts on fruit ripening, have been well established [45-47]. A study by Fulton et al. [48] suggested that to reduce ethylene release and its adverse effects on plants, biochar should be stored in an open environment for 90 days prior to use in nursery plants. Although not measured in this study, the likely presence of ethylene in the biochar used could have affected 
plant growth (as discussed below) and some fruit quality attributes. The production of ethylene from biochar and its role on root growth remains an interesting mechanism to be investigated.

\subsection{Fruit Quality at Harvest}

To date, information on the effects of biochar on the tomato yield and quality are still scarce [49]. Color and firmness of tomatoes are important quality attributes because they are highly correlated with sensory attributes, such as taste and aroma [50]. For simplicity, only the $L^{*}$ (lightness), a* (redness), and hue angle were reported in this study (Figure 2). Tomato fruit from plants grown in media amended with biochar pyrolized at lower or higher than $450{ }^{\circ} \mathrm{C}$ had a darker red color (higher $\mathrm{a}^{*}$ values) than fruit from other treatments (Figure 2). The hue angle of full red tomato is generally within the range of $30^{\circ}$ to $50^{\circ}$, with lower values indicating deeper red or purple color and higher values indicating a more orange color [51]. In this study, the small range (38-42) in the hue angle values of tomatoes from different treatments indicated that fruit were roughly at the same color stage (Figure 2). Increased $\mathrm{a}^{*}$ values have shown to be directly associated with lycopene synthesis, whereas the $\mathrm{a}^{*} / \mathrm{b}^{*}$ ratio has been reported to be a good indicator of lycopene content and therefore could be used to characterize the tomato ripeness stage [23,52].
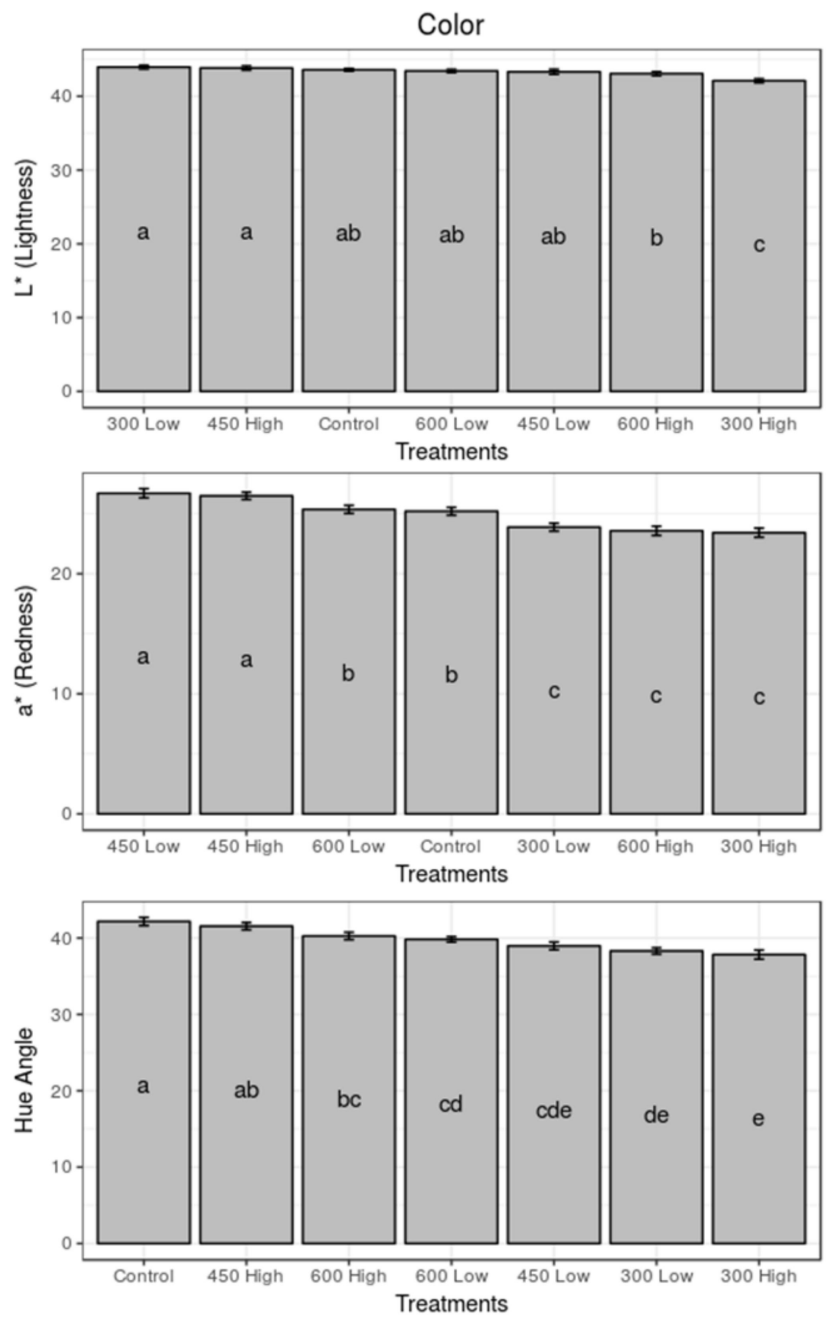

Figure 2. Color coordinates, $\mathrm{a}^{*}, \mathrm{~L}^{*}$, and hue angle values, of tomatoes cultivated in the standard (control) and biochar amended media. Bars represent standard error $(n \approx 30)$. Different letters show significant difference $(p<0.05)$ between treatments. 
Fruit from the 600 High treatment were significantly larger and firmer than the control. Fruit from the 300 Low treatments were larger, while those produced from the 450 High and 450 Low were firmer compared to the control and other treatments (Figure 3). Tomato firmness is an important attribute because it is associated with good eating quality and longer postharvest life [24]. Appearance of the fruit were qualitatively evaluated for differences in locular structure and seed population, showing no significant differences amongst treatments (data not shown). Petruccelli et al. [19] evaluated effects of three different types of biochars (wheat straw biochar, poplar biochar, and olive residues biochar) at concentrations of $10 \%$ and $20 \%(w / w)$ on tomato growth, and also found no significant differences in fruit size and weight amongst treatments.

Reducing sugars, such as glucose and fructose, are the major components of the SSC with the remainder consisting of organic acids, lipids, minerals, and pigments. Both SSC and sugar levels (fructose and glucose) of biochar-treated fruit were significantly higher than the control. However, fructose, glucose, and SSC where higher in fruits from the 300 Low treatment compared to the control (Figure 4). These results are in agreement with previously published data that show mature tomatoes having SSC ranging from 4.5 to $8.5 \%$ of its fresh weight [53].
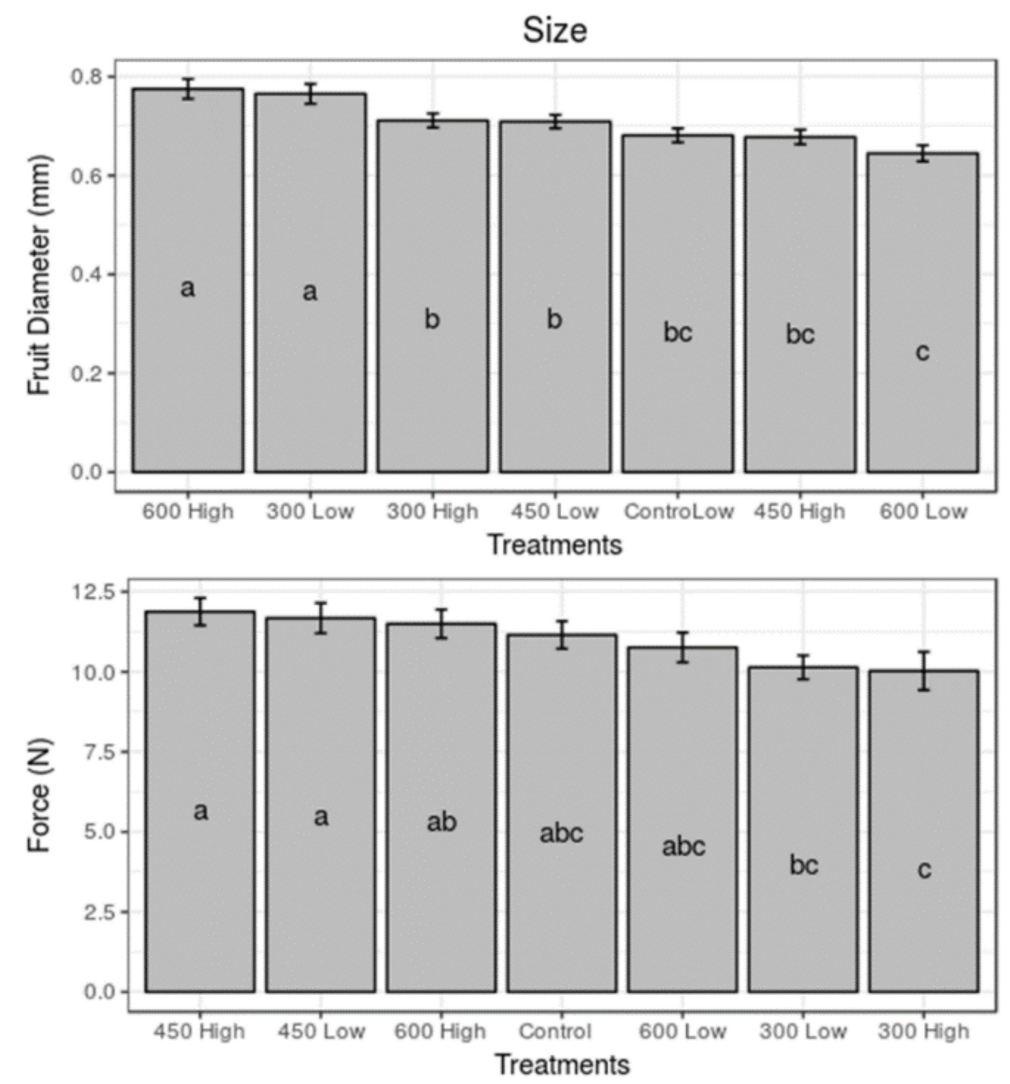

Figure 3. Fruit size (diameter) and firmness of tomatoes cultivated in the standard (control) biochar amended media. Bars represent standard error $(n \approx 30)$. Different letters show significant difference $(p<0.05)$ between treatments. 

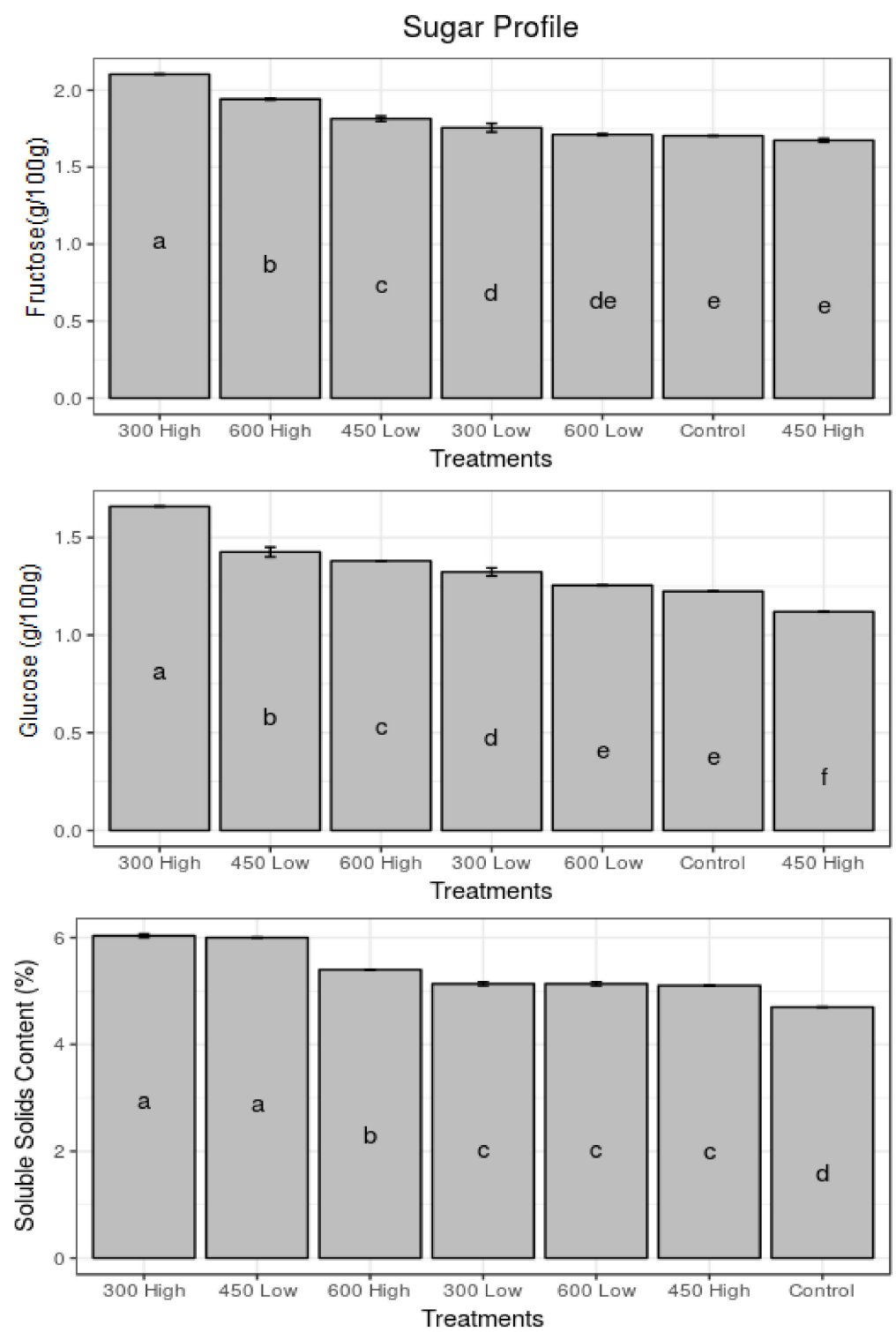

Figure 4. Soluble solids content (SSC), fructose, and glucose contents of tomatoes cultivated in the standard (control) and biochar amended media. Bars represent standard error $(n=6$ for fructose and glucose and $n=3$ for SSC). Different letters show significant difference $(p<0.05)$ between treatments.

Organic acids measured as a percentage of citric acid and AA content showed that fruits treated with lower temperature biochars tended to have higher acidity and lower AA levels than the other treatments (Figure 5). In a previous study, Petruccelli, Bonetti, Traversi, Faraloni, Valagussa and Pozzi [19] also showed that the type of feedstock influenced the biochar soil amendment and found that tomatoes (cv. Rio Grande) grown in a substrate amended with biochars made from straw and olive residues produced at $1200{ }^{\circ} \mathrm{C}$ had higher secondary metabolites, phenolic compounds, and lycopene compared to those grown in a poplar biochar amended soil. As tomatoes mature on the plant, sugar-to-acid ratio increases, resulting in higher soluble solids and lower acidity [24]. The sugar-to-acid ratio for the $300 \mathrm{High}, 450 \mathrm{High}$, and $600 \mathrm{High}$ treatments were significantly higher than the control, indicating higher maturity or difference in flavor (Figure 6). 

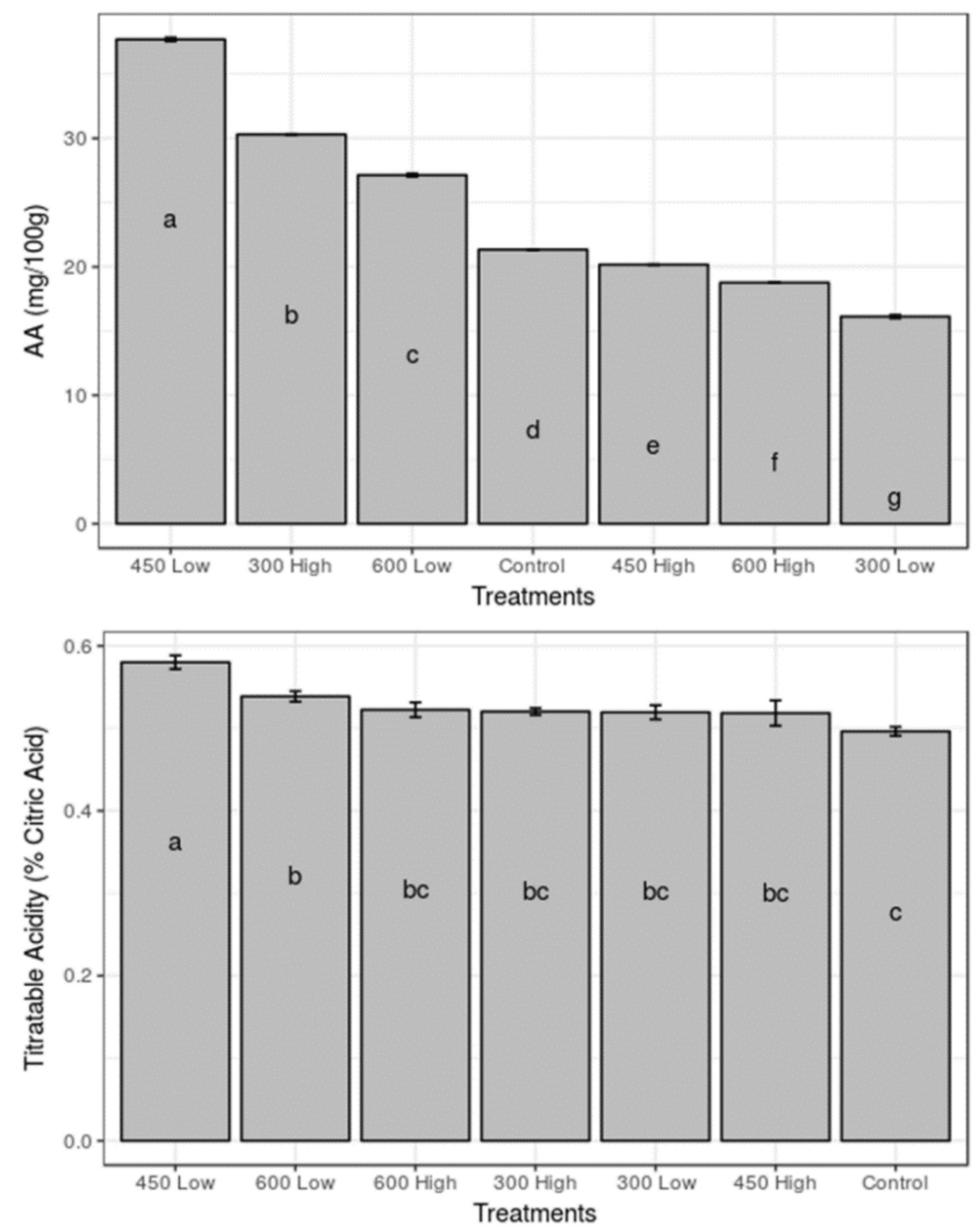

Figure 5. Total ascorbic acid (AA) and titratable acidity (TA) of tomatoes cultivated in the standard (control) and biochar amended media. Bars represent standard error ( $n=6$ for AA and $n=3$ for TA). Different letters show significant difference $(p<0.05)$ between treatments.

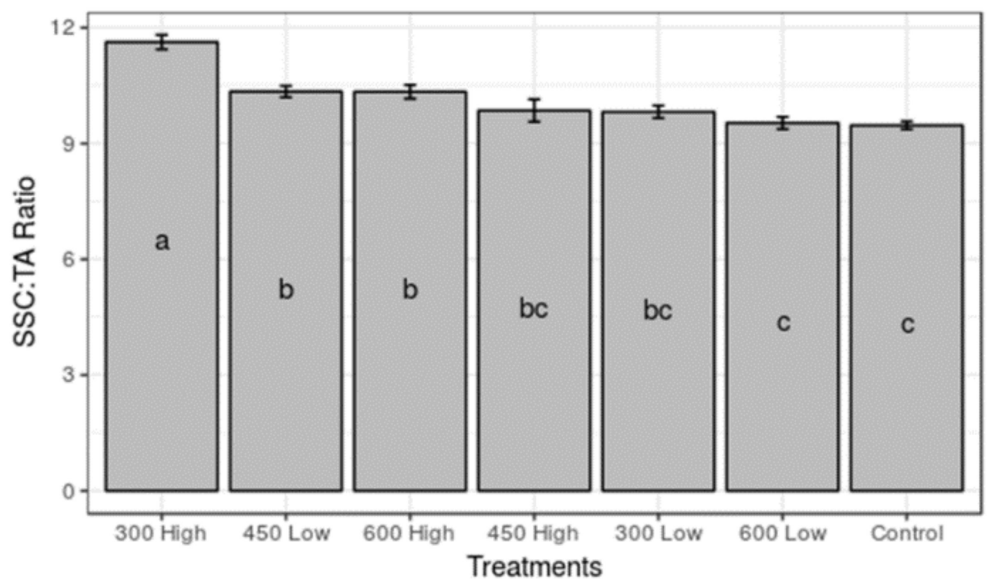

Figure 6. Statistical analysis of sugar-to-acid ratio of tomato fruits cultivated in the standard (control) and biochar amended media. Bars represent standard error. Different letters show significant difference $(p<0.05)$ between treatments.

\section{Conclusions}

This is the first study to show that biochars pyrolyzed at different temperatures when amended to a soil at different rates affect tomato growth and fruit quality. Overall, lower temperature biochars, 
particularly those produced at $300^{\circ} \mathrm{C}$, had the most significant effect on plant growth and a positive effect on fruit quality. Also, lower temperature biochar treatments produced firmer fruit with a darker red color, higher sugar and acids levels, and potentially higher nutritional value as indicated by a higher content of vitamin C (ascorbic acid). Since the sugar-to-acid ratios and hue angle values amongst the treatments were not significantly different, this indicated that the fruit were at a similar maturity stage. Hence, the superior quality of these tomato fruit can be attributed to the biochar treatments and not to the difference in the maturity of the fruit. Thus, biochar may have contributed to an increase in nutritional quality of the fruit. Furthermore, an effect on ripening physiology (hormonal regulation) should also be considered. This study also showed that the medium amended with biochar pyrolyzed at $300{ }^{\circ} \mathrm{C}$ had the highest mean concentration of $\mathrm{NO}_{3}-\mathrm{N}, \mathrm{P}, \mathrm{Ca}$, and $\mathrm{Mg}$. These concentrations are well within recommended ranges for tomato production, thus plant growth and fruit quality were improved. This may provide an explanation for the increased plant growth and improved fruit quality and a promising use of biochar for soil amendment.

Author Contributions: R.G.S., M.C.N.N., J.C., and B.G. conceived the study; R.G.S. and C.W. conducted the experiments and collected the data; all the authors contributed to data interpretation; and R.A.S., M.C.N.N., J.C., S.A.S., R.A.B., and B.G. contributed to the writing of the paper.

Funding: This research was partially supported by the NSF through CBET-1054405.

Conflicts of Interest: The authors declare no conflict of interest.

\section{References}

1. Hussain, M.; Farooq, M.; Nawaz, A.; Al-Sadi, A.M.; Solaiman, Z.M.; Alghamdi, S.S.; Ammara, U.; Ok, Y.S.; Siddique, K.H. Biochar for crop production: Potential benefits and risks. J. Soils Sediments 2017, 17, 685-716. [CrossRef]

2. Lehmann, J. Bio-energy in the black. Front Ecol. Environ. 2007, 5, 381-387. [CrossRef]

3. Sohi, S.P.; Krull, E.; Lopez-Capel, E.; Bol, R. A Review of Biochar and Its Use and Function in Soil. Adv. Agron. 2010, 105, 47-82.

4. Spokas, K.A. Review of the stability of biochar in soils: Predictability of O: C molar ratios. Carbon Manage. 2010, 1, 289-303. [CrossRef]

5. Lehmann, J.; Joseph, S. Biochar for Environmental Management: Science, Technology and Implementation. Routledge: New York, UK, USA, 2015.

6. Downie, A.; Crosky, A.; Munroe, P. Physical Properties of Biochar. In Biochar for Environmental Management: Science and Technology; Lehmann, J., Joseph, S., Eds.; Routledge: New York, NY, USA, 2009; pp. 13-32.

7. Wang, S.S.; Gao, B.; Zimmerman, A.R.; Li, Y.C.; Ma, L.N.; Harris, W.G.; Migliaccio, K.W. Physicochemical and sorptive properties of biochars derived from woody and herbaceous biomass. Chemosphere 2015, 134, $257-262$. [CrossRef] [PubMed]

8. Sun, Y.; Gao, B.; Yao, Y.; Fang, J.; Zhang, M.; Zhou, Y.; Chen, H.; Yang, L. Effects of feedstock type, production method, and pyrolysis temperature on biochar and hydrochar properties. Chem. Eng. J. 2014, 240, 574-578. [CrossRef]

9. Keith, A.; Singh, B.; Singh, B.P. Interactive Priming of Biochar and Labile Organic Matter Mineralization in a Smectite-Rich Soil. Environ. Sci. Technol. 2011, 45, 9611-9618. [CrossRef] [PubMed]

10. Quilliam, R.S.; Marsden, K.A.; Gertler, C.; Rousk, J.; DeLuca, T.H.; Jones, D.L. Nutrient dynamics, microbial growth and weed emergence in biochar amended soil are influenced by time since application and reapplication rate. Agr. Ecosyst. Environ. 2012, 158, 192-199. [CrossRef]

11. Liu, X.; Zhang, A.; Ji, C.; Joseph, S.; Bian, R.; Li, L.; Pan, G.; Paz-Ferreiro, J. Biochar's effect on crop productivity and the dependence on experimental conditions-a meta-analysis of literature data. Plant Soil 2013, 373, 583-594. [CrossRef]

12. Olmo, M.; Alburquerque, J.A.; Barrón, V.; Del Campillo, M.C.; Gallardo, A.; Fuentes, M.; Villar, R. Wheat growth and yield responses to biochar addition under Mediterranean climate conditions. Biol. Fert. Soils 2014, 50, 1177-1187. [CrossRef]

13. Olmo, M.; Villar, R.; Salazar, P.; Alburquerque, J.A. Changes in soil nutrient availability explain biochar's impact on wheat root development. Plant Soil 2016, 399, 333-343. [CrossRef] 
14. Schumann, A. Opportunities for biochar production and use in Florida citrus. Citrus Ind. 2012, 4, 6-9.

15. Atkinson, C.J.; Fitzgerald, J.D.; Hipps, N.A. Potential mechanisms for achieving agricultural benefits from biochar application to temperate soils: a review. Plant Soil 2010, 337, 1-18. [CrossRef]

16. Major, J.; Rondon, M.; Molina, D.; Riha, S.J.; Lehmann, J. Maize yield and nutrition during 4 years after biochar application to a Colombian savanna oxisol. Plant Soil 2010, 333, 117-128. [CrossRef]

17. Spokas, K.A.; Cantrell, K.B.; Novak, J.M.; Archer, D.W.; Ippolito, J.A.; Collins, H.P.; Boateng, A.A.; Lima, I.M.; Lamb, M.C.; McAloon, A.J. Biochar: A synthesis of its agronomic impact beyond carbon sequestration. J. Environ. Qual. 2012, 41, 973-989. [CrossRef] [PubMed]

18. Biederman, L.A.; Harpole, W.S. Biochar and its effects on plant productivity and nutrient cycling: A meta-analysis. GCB Bioenergy 2013, 5, 202-214. [CrossRef]

19. Petruccelli, R.; Bonetti, A.; Traversi, M.L.; Faraloni, C.; Valagussa, M.; Pozzi, A. Influence of biochar application on nutritional quality of tomato (Lycopersicon esculentum). Crop Pasture Sci. 2015, 66, 747-755. [CrossRef]

20. Sun, H.-J.; Uchii, S.; Watanabe, S.; Ezura, H. A highly efficient transformation protocol for Micro-Tom, a model cultivar for tomato functional genomics. Plant Cell Physiol. 2006, 47, 426-431. [CrossRef] [PubMed]

21. Gomez, P.; Ferrer, M.; Fern\&\#xE1ndez-Trujillo, J.P.; Calder\&\#xF3n, A.; Art\&\#xE9s, F.; Egea-Cortines, M.; Weiss, J. Structural changes, chemical composition and antioxidant activity of cherry tomato fruits (cv. Micro-Tom) stored under optimal and chilling conditions. J. Sci. Food Agr. 2009, 89, 1543-1551. [CrossRef]

22. Brandt, S.; Pék, Z.; Barna, É.; Lugasi, A.; Helyes, L. Lycopene content and colour of ripening tomatoes as affected by environmental conditions. J. Sci. Food Agr. 2006, 86, 568-572. [CrossRef]

23. Helyes, L.; Pék, Z.; Lugasi, A. Tomato fruit quality and content depend on stage of maturity. Hort. Sci. 2006, 41, 1400-1401.

24. Nunes, C. Color Atlas of Postharvest Quality of Fruits and Vegetables; Wiley-Blackwell, Blackwell Publishing: Ames, IA, USA, 2008.

25. Baldwin, E.; Scott, J.; Einstein, M.; Malundo, T.; Carr, B.; Shewfelt, R.; Tandon, K. Relationship between sensory and instrumental analysis for tomato flavor. J. Am. Soc. Hortic. Sci. 1998, 123, 906-915.

26. Shewfelt, R.L. Sources of variation in the nutrient content of agricultural commodities from the farm to the consumer. J. Food Qual. 1990, 13, 37-54. [CrossRef]

27. Schmidt, H.-P.; Kammann, C.; Niggli, C.; Evangelou, M.W.; Mackie, K.A.; Abiven, S. Biochar and biochar-compost as soil amendments to a vineyard soil: Influences on plant growth, nutrient uptake, plant health and grape quality. Agr. Ecosyst. Environ. 2014, 191, 117-123. [CrossRef]

28. Akhtar, S.S.; Li, G.; Andersen, M.N.; Liu, F. Biochar enhances yield and quality of tomato under reduced irrigation. Agr. Water Manage. 2014, 138, 37-44. [CrossRef]

29. Inyang, M.; Gao, B.; Pullammanappallil, P.; Ding, W.; Zimmerman, A.R. Biochar from anaerobically digested sugarcane bagasse. Bioresour. Technol. 2010, 101, 8868-8872. [CrossRef] [PubMed]

30. Chen, J.; Beeson, R.C., Jr. Actual evapotranspiration of Asplenium nidus and Chamaedorea elegans during production from liners to marketable plants. Acta Hortic. 2013, 990, 339-344. [CrossRef]

31. Yeager, T.; Wright, R.; Donohue, S. Comparison of pour-through and saturated pine bark extract N, P, K, and $\mathrm{pH}$ [nitrogen, phosphorus, potassium and hydrogen ion concentration] levels [Soil testing, soilless media, nutrient extraction]. J. Am. Soc. Hortic. Sci. 1983, 108, 112-114.

32. Nunes, M.C.d.N. Correlations between subjective quality and physicochemical attributes of fresh fruits and vegetables. Postharvest Biol. Tec. 2015, 107, 43-54. [CrossRef]

33. Nunes, M.C.N.; Delgado, A. Quality of Organic Compared to Conventionally Grown Strawberries at the Retail Level. International Society for Horticultural Science (ISHS): Leuven, Belgium, 2014; pp. 723-730.

34. De Mendiburu, F.; de Mendiburu, M.F. Package 'agricolae'. Version 3.1.1. 2015.

35. Yao, Y.; Gao, B.; Inyang, M.; Zimmerman, A.R.; Cao, X.; Pullammanappallil, P.; Yang, L. Biochar derived from anaerobically digested sugar beet tailings: Characterization and phosphate removal potential. Bioresour. Technol. 2011, 102, 6273-6278. [CrossRef] [PubMed]

36. Lehmann, J.; Rillig, M.C.; Thies, J.; Masiello, C.A.; Hockaday, W.C.; Crowley, D. Biochar effects on soil biota-A review. Soil Biol. Biochem. 2011, 43, 1812-1836. [CrossRef]

37. Yuan, J.-H.; Xu, R.-K.; Zhang, H. The forms of alkalis in the biochar produced from crop residues at different temperatures. Bioresour. Technol. 2011, 102, 3488-3497. [CrossRef] [PubMed] 
38. Shen, Z.; Zhang, Y.; McMillan, O.; Jin, F.; Al-Tabbaa, A.J.E.S. Characteristics and mechanisms of nickel adsorption on biochars produced from wheat straw pellets and rice husk. Environ. Sci. Pollut. Res. 2017, 24, 12809-12819. [CrossRef] [PubMed]

39. Singh, B.P.; Cowie, A.L.; Smernik, R.J. Biochar Carbon Stability in a Clayey Soil As a Function of Feedstock and Pyrolysis Temperature. Environ. Sci. Technol. 2012, 46, 11770-11778. [CrossRef] [PubMed]

40. Glaser, B.; Lehmann, J.; Zech, W. Ameliorating physical and chemical properties of highly weathered soils in the tropics with charcoal-a review. Biol. Fert. Soils 2002, 35, 219-230. [CrossRef]

41. Lehmann, J.; da Silva, J.P., Jr.; Steiner, C.; Nehls, T.; Zech, W.; Glaser, B. Nutrient availability and leaching in an archaeological Anthrosol and a Ferralsol of the Central Amazon basin: Fertilizer, manure and charcoal amendments. Plant Soil 2003, 249, 343-357. [CrossRef]

42. Graber, E.; Tsechansky, L.; Gerstl, Z.; Lew, B. High surface area biochar negatively impacts herbicide efficacy. Plant Soil 2012, 353, 95-106. [CrossRef]

43. Laird, D.; Fleming, P.; Wang, B.; Horton, R.; Karlen, D. Biochar impact on nutrient leaching from a Midwestern agricultural soil. Geoderma 2010, 158, 436-442. [CrossRef]

44. Spokas, K.A.; Baker, J.M.; Reicosky, D.C. Ethylene: Potential key for biochar amendment impacts. Plant Soil 2010, 333, 443-452. [CrossRef]

45. Abeles, F.; Morgan, P.; Saltveit, M., Jr. Ethylene in Plant Biology; Elsevier Science Publishing Co Inc: San Diego, CA, USA, 1992.

46. Frankenberger, W.T., Jr.; Arshad, M. Phytohormones in Soils: Microbial Production and Function; Marcel Dekker Inc.: New York, UK, USA, 1995.

47. Arshad, M.; Frankenberger, W.T., Jr. Ethylene: Agricultural Sources and Applications; Springer Science \& Business Media: New York, UK, USA, 2012.

48. Fulton, W.; Gray, M.; Prahl, F.; Kleber, M. A simple technique to eliminate ethylene emissions from biochar amendment in agriculture. Agron. Sustain. Dev. 2013, 33, 469-474. [CrossRef]

49. Vaccari, F.P.; Maienza, A.; Miglietta, F.; Baronti, S.; Di Lonardo, S.; Giagnoni, L.; Lagomarsino, A.; Pozzi, A.; Pusceddu, E.; Ranieri, R.; Valboa, G.; Genesio, L. Biochar stimulates plant growth but not fruit yield of processing tomato in a fertile soil. Agr. Ecosyst. Environ. 2015, 207, 163-170. [CrossRef]

50. Resurreccion, A.; Shewfelt, R. Relationships between sensory attributes and objective measurements of postharvest quality of tomatoes. J. Food Sci. 1985, 50, 1242-1245. [CrossRef]

51. Perkins-Veazie, P.; Roberts, W.; Collins, J.K. Lycopene content among organically produced tomatoes. J. Veg. Sci. 2007, 12, 93-106. [CrossRef]

52. Arias, R.; Lee, T.-C.; Logendra, L.; Janes, H. Correlation of lycopene measured by HPLC with the $L^{*}, a^{*}, b^{*}$ color readings of a hydroponic tomato and the relationship of maturity with color and lycopene content. J. Agr. Food Chem. 2000, 48, 1697-1702. [CrossRef]

53. Pedro, A.M.; Ferreira, M.M. Nondestructive determination of solids and carotenoids in tomato products by near-infrared spectroscopy and multivariate calibration. Anal. Chem. 2005, 77, 2505-2511. [CrossRef] [PubMed]

(C) 2018 by the authors. Licensee MDPI, Basel, Switzerland. This article is an open access article distributed under the terms and conditions of the Creative Commons Attribution (CC BY) license (http://creativecommons.org/licenses/by/4.0/). 